\title{
DETSKÝ ELEMENT V ZRKADLE ARCHEOLOGICKÝCH PRAMEŇOV VČASNÉHO STREDOVEKU
}

\author{
MARTINA MOLNÁROVÁ - ZUZANA BORZOVÁ
}

\begin{abstract}
Abstrakt: Príspevok ponúka exkurz do problematiky detstva a detí vo včasnom stredoveku z pohl'adu archeológie. Pramennú bázu tvoria detské hroby zo 6.-12. storočia z územia Slovenska s počtom 2661 zo 134 lokalit. Prostredníctvom analýzy a vyhodnotenia hrobového inventára, ako aj elementov pohrebného ritu detských hrobov je možné postrehnút' niektoré špecifické úkazy, ktoré demonštrujú postavenie detí, resp. ich rolu v súvekej spoločnosti. Pozornost' je venovaná otázke sociálneho postavenia detských jedincov, možným archeologickým dokladom starostlivosti o deti, problematike roly detí v konkrétnej spoločnosti, ako aj otázke nehumánneho zaobchádzania s det'mi.
\end{abstract}

Kl'účové slová: detski jedinci-včasný stredovek - detské hroby-inventár-postavenie detí.

\section{The Child Element in the Light of Archaeological Sources from the Early Middle Ages}

\begin{abstract}
This paper offers an insight into the subject of childhood in the early Middle Ages from the perspective of archaeology. Its source base draws on children's graves from the 6th-12th centuries in Slovak territory, in total 2,661 from 134 sites. Through the analysis and assessment of grave goods as well as the elements of burial rites connected with children's graves it is possible to observe some specific phenomena that illustrate the status of children and their role in medieval society. Attention is also paid to the social status of children, possible archaeological evidence of childcare and the part children played in a particular community, as well as to the inhumane treatment of children.
\end{abstract}

Key words: children - early Middle Ages - children's graves - grave goods - children's status.

Problematika detí a detstva sa postupne, najmä v posledných dvoch dekádach, začala čoraz viac dostávat' do popredia záujmu archeologickej, antropologickej i d’alšej odbornej verejnosti. V archeológii sa tento záujem začal prejavovat' už koncom 70. a začiatkom 80. rokov, no naplno sa rozvinul až v 90. rokoch 20. storočia (napríklad Butler 1990; Gilchrist 1991; Lillehammer 1989; Maynard-Thomas 2004; Moore-Scott 1997; Sofaer-Derevenski 1994; 1997 a i.). Otázka postavenia detských členov v rámci hierarchie jednotlivých komunít, „detský život“ v pravom slova zmysle, vzt’ah dospelých a detských jedincov v rámci jedného spoločenstva - to sú otázky, na ktoré sa v súčasnej dobe snaží odpovedat' značná čast' odbornej verejnosti venujúcej sa uvedenej problematike aj v stredoeurópskom prostredí (Hanuliak 2006; 2010; Chorvátová 2009; 2012; Krekovič 2011; Měchurová 2010; Nodl 1996; 2006; Profantová 2005; Slivka 1998; 2014; Smetánka 1992; 1993; 2003; Unger 2002; 2007). Začína prevládat' trend interdisciplinárneho výskumu, ked' sa diet’a nevníma len z kvantitatívneho hladiska ako súčast' populácie na pohrebisku, ale berú sa do úvahy i d’alšie doplňujúce informácie, ktoré je možné získat' z nálezových kontextov. Primárnym ciel'om je pokus o rekonštrukciu života jedincov nielen ako jednotlivcov, ale aj ako členov konkrétnej society v určitom čase a priestore. Napriek tomu, že bez interdisciplinárnej spolupráce nie je možné fenomén detstva vo včasnom stredoveku rekonštruovat', pre stredoeurópsky priestor je primárnym informačným zdrojom práve archeologický materiál.

Pramennú bázu k danej téme predstavujú predovšetkým detské hroby zo 6.-12. storočia z územia Slovenska. Z doposial' publikovaných zdrojov identifikujeme 3469 detských hrobov všetkých vekových kategórií zo 142 včasnostredovekých lokalít (6.-12. storočie) z územia Slovenska. Východisková pramenná báza zahŕňa však „iba“ vekové kategórie infans I. a II. (0-14 rokov), ktoré predstavujú 2661 jedincov zo 134 lokalít. V prevažnej väčšine ide o ploché kostrové pohrebiská, pät' mohylníkov (z toho štyri birituálne a jeden žiarový), tri lokality s výskytom pohrebu detí v areáli sídliska, jeden sídliskový objekt $\mathrm{s}$ detským hrobom a šest' ojedinelých hrobov detských jedincov (Molnárová 2015, 25-26). Najviac lokalít z hodnoteného súboru predstavujú malé až stredne vel'ké pohrebiská s počtom hrobov do sto. Najväčší a kvalitatívne najreprezentatívnejší súbor z hl'adiska analýzy detských hrobov poskytujú rozsiahle viacgeneračné pohrebiská, ktoré sa objavujú len sporadicky (graf 1;2). Zastúpenie hrobov detských jedincov 
počas jednotlivých fáz včasného stredoveku nie je vyrovnané. Nadpolovičná väčšina pochádza z pohrebísk z obdobia avarského kaganátu, práve kvôli rozsiahlym nekropolám, ktoré sú v hodnotenom období analyzované. Za ním nasleduje súbor z 9 . storočia, v ktorom je doložených $23 \%$ a nakoniec sú to detské hroby z obdobia po 9 . storočí, ktoré predstavujú $13 \%$ z celkového počtu analyzovaných detských hrobov z obdobia včasného stredoveku (graf 3).

Okrem vyššie vymenovaných aspektov pohrebného rítu sú pri analýze sledované aj d’alšie elementy, ktoré však pri väčšine detských hrobov nie je možné kvôli absencii informácií sumárne vyhodnotit'. Ide o zachovanie skeletu detských jedincov (v 60 \% prípadoch boli kostričky detí strávené), o umiestnenie detských hrobov v rámci samotného pohrebiska (absentuje v $90 \%$ prípadoch), o určenie veku detských jedincov (absentuje v 64 \% prípadoch), o určenie pohlavia (absentuje v $46 \%$ prípadoch).

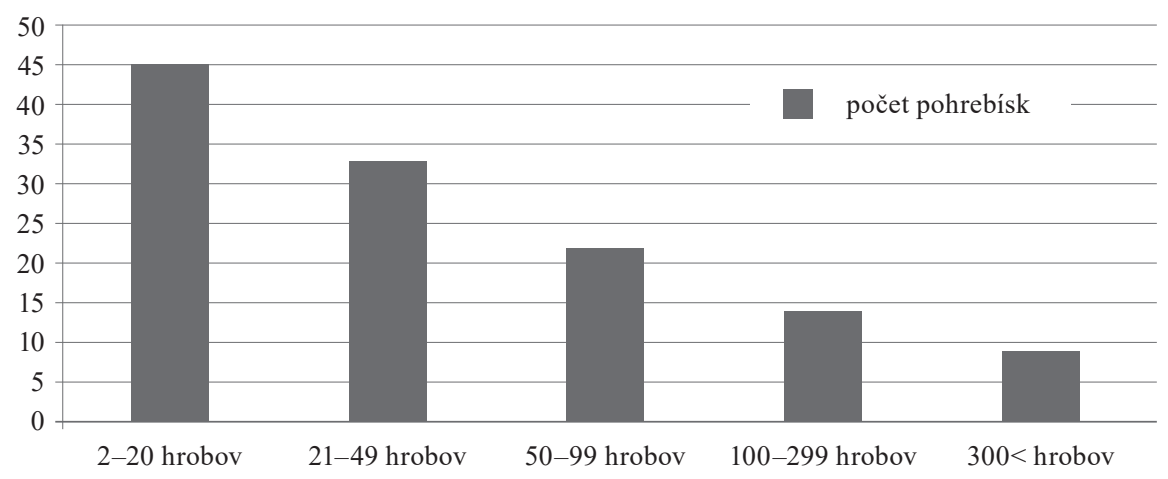

Graf 1. Pohrebiská podl’a počtu hrobov zo věasného stredoveku na Slovensku.

Diagramm 1. Gräberfelder in der Slowakei entsprechend der Anzahl ihrer Gräber aus dem Frühmittelalter.

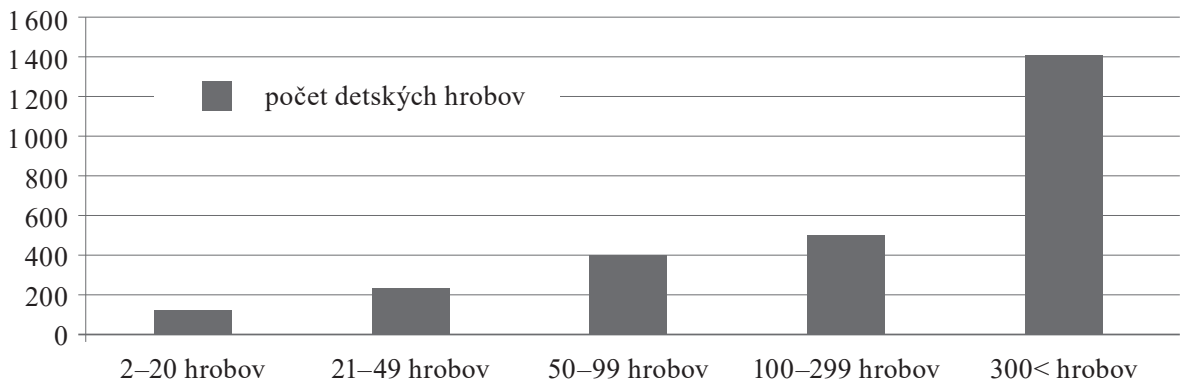

Graf 2. Počet detských hrobov na včasnostredovekých pohrebiskách rozdelených podl’a početnosti hrobov.

Diagramm 2. Anzahl der Kindergräber auf frühmittelalterlichen Gräberfeldern untergliedert nach Häufigkeit der Gräber.

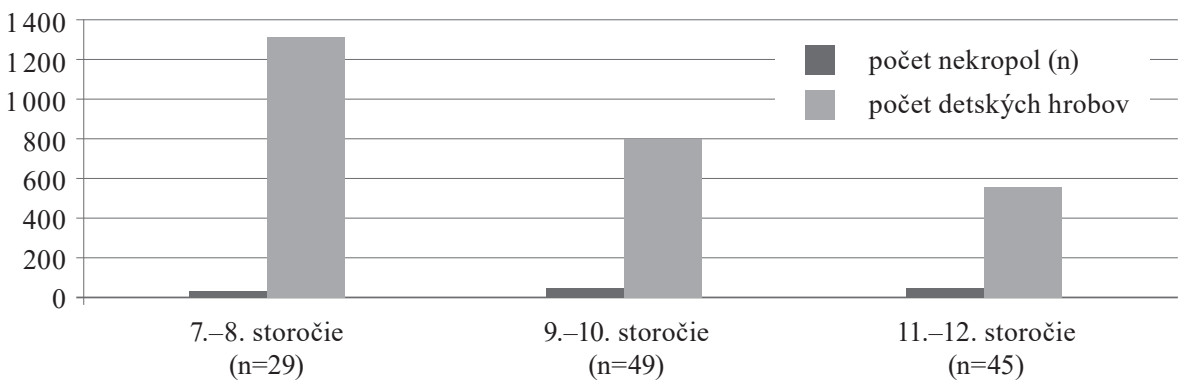

Graf 3. Pomerné zastúpenie detských hrobov na nekropolách z jednotlivých úsekov včasného stredoveku.

Diagramm 3. Proportionales Vorkommen von Kindergräbern auf Nekropolen aus den einzelnen Abschnitten des Frühmittelalters. 
Ďalším dôležitým zdrojom informácí je inventár z detských hrobov, teda predmety, ktoré $\mathrm{v}$ interpretačnej rovine môžeme priradit' $\mathrm{k}$ danej téme. Tvoria ho predovšetkým rôzne druhy šperku, apotropajné predmety, zbrane a súčasti militárií, predmety dennej potreby, ako i množstvo organického a neorganického materiálu (inventár sa nachádza v 61 \% hrobov).

Prostredníctvom vyššie vymenovaných archeologických prameňov je možné postrehnút' niektoré špecifické javy, ktoré vypovedajú o rôznych sférach života detí a o ich role v súvekej spoločnosti. Pomocou predloženého príspevku sa pokúsime načrtnút' niektoré z nich.

Jedným z nich je otázka sociálneho postavenia detských jedincov v danej spoločnosti. Tá bola riadená určitými pravidlami a normami, platnými pre všetkých jej členov, nevynímajúc tých najmenších - deti. Postavenie nielen detí, ale všeobecne každého jedinca v súvekej pospolitosti, resp. úroveň spoločenskej diferenciácie v stredoeurópskom priestore, možno sčasti demonštrovat' prostredníctvom archeologických prameňov. V archeologickom materiáli sa sociálna diferenciácia detských jedincov prejavuje vo vel'kej miere analogickými javmi, ktoré možno sledovat' u dospelých elitných jedincov na kostrových pohrebiskách a cintorínoch od polovice 7. po polovicu 11. storočia. V jednotlivých časových horizontoch včasného stredoveku vplyvom odlišného spoločenského a kultúrno-etnického vývoja možno sledovat' hodnotený jav v určitých odchýlkach.

Už v období avarského kaganátu sa vyššie zmienený fenomén prejavuje prítomnostou detských ,jazdeckých hrobov“. Evidujeme ich na šiestich pohrebiskách zo skúmaného územia. Ide o 18 detských jedincov s atribútmi, ktoré sú analogické s hrobmi dospelých jazdcov - elitnej skupiny avarskej society. Podobne ako hroby dospelých jazdcov, aj tie detské sú charakteristické špeciálnym pohrebným rítom, ked’ je do hrobu vložená kostra koňa alebo jeho časti. Vo väčšine týchto detských hrobov (v 68 \%) je kôň uložený po l’avej ruke ,jazdca“ v rovnakom smere a s orientáciou severozápad-juhovýchod, podobne ako pri dospelých jazdcoch (Zábojník 2004, 35). Ostatné detské ,jazdecké hroby“, všetky z pohrebiska v Košiciach-Šebastovciach, sú orientované v smere východ-západ a vyznačujú sa polohou koňa v opačnom smere, väčšinou po pravici ,jazdca“ (Budinský-Krička-Točík 1991). Jazdecké hroby, okrem zmieneného špeciálneho pohrebného rítu, sú charakteristické bohatým hrobovým inventárom, ktorý v prípade dospelých jedincov dokladá najmä sociálny status pochovaného (Zábojník 2004, 41). S rovnako honosnými predmetmi sa stretávame aj v hrobovej výbave detských jedincov. Ide predovšetkým o zbrane (hlavne hroty kopijí, šípov, dýky, časti luku, šabl’a a i.), liate súčasti opaskovej garnitúry a konského postroja, honosné šperky, ako aj o predmety dennej potreby a i. V súvislosti s hrobovou výbavou týchto detí je zaujímavý poznatok, že vo viacerých prípadoch sú hroby mladších detí (infans I. a II.) vybavené ovel’a honosnejšie ako v prípade tých starších (juvenis). Príkladom sú dva najbohatšie vybavené ,jazdecké“ detské hroby zo súboru, oba patriace jedincom s antropologickým určením veku infans I., v rozmedzí jedného až troch rokov (Jakab 1993, 311; Jakab-Vondráková 1982, 398). Zároveň ide aj o najmladšie deti pochované samostatne v hroboch s atribútmi jazdca. Je to hrob 11 z Komárna-Váradiho ulice (Čilinská 1982, 349) a hrob 109 z pohrebiska v Komárne-Lodenica II. (Trugly 1993, 198). Hrob 11 obsahoval bohato zdobené a pozlátené súčasti opaska, kopiju i dýku, súčasti konského postroja, dve zlaté hrozienkové náušnice a dokonca i bronzovú rol'ničku (obr. 1). Vyslovene mužské atribúty, akými sú opasok, konský postroj a zbrane - typické predmety bojovníka, definujú i jeho sociálny status.

Okrem vyššie zmienených detských ,,jazdeckých“ hrobov sa v období avarského kaganátu na súdobých pohrebiskách stretávame aj s bohato vybavenými detskými hrobmi bez prítomnosti koňa. Aj pri nich je dominantná orientácia v smere severozápad-juhovýchod (s odchýlkami $\mathrm{S}$ a Z) a bohatý inventár, ktorý je okrem súčastí konského postroja porovnatel’ný s detskými ,jazdeckými hrobmi““ (napríklad Zábojník 2015). Niektoré z nich dokonca nesú stopy po drevenej úprave. Deti v týchto hroboch boli pochované na drevených doskách, v drevených truhlách, pod drevenými kolovými konštrukciami a ojedinele na márach (obr. 2). Poznáme aj hroby upravené kameňom v podobe kamenných vencov alebo okruhliakových hniezd.

Na pohrebiskách z 9. a 10. storočia sa takisto stretávame s hrobmi, ktoré majú nadštandardnú výbavu. Ide o predmety predstavujúce symbol vysokého sociálneho postavenia: militárie a súčasti jazdeckého výstroja, ako aj rôzne druhy šperku, súčasti odevu a kovania opasku. 

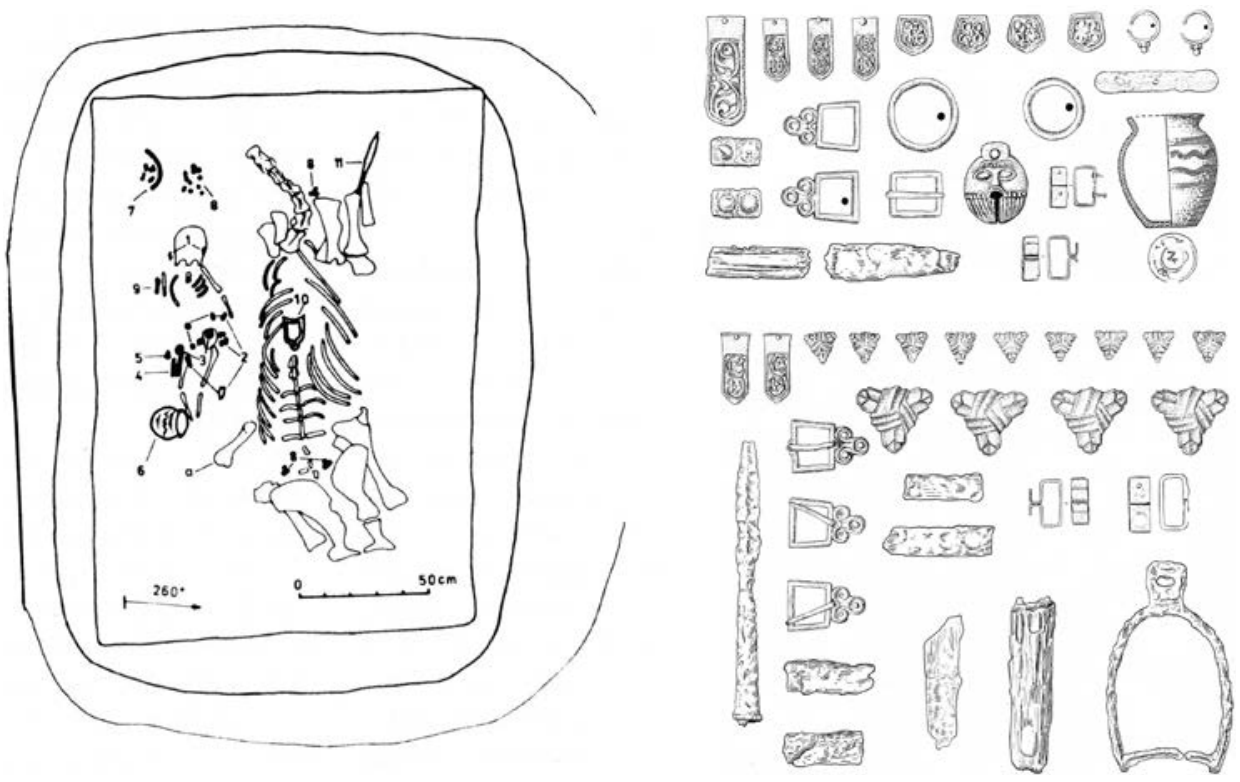

Obr. 1. Detský hrob 11 z Komárna, poloha Váradiho ul., s prítomnostou koňa v rovnakej orientácii a s bohatou výbavou. Podl'a Čilinská 1982, 350, obr. 1:5; 376, tab. IV:21-43; V:1-27, upravené.

Abb. 1. Kindergrab 11 in Komárno, Lage Váradi-Str. mit Pferd in gleicher Orientierung und reicher Grabausstattung. Nach Čilinská 1982, 350, Abb. 1:5; 376, Taf. IV:21-43; V:1-27, bearbeitet.

Militárie, ako aj súčasti jazdeckého výstroja (predovšetkým ostrohy) vyjadrujú spoločenský status elitnej zložky vtedajšej spoločnosti - bojovníkov. Tieto predmety sa vyskytujú v hroboch dospelých aj detských jedincov. Jedným z nich sú ostrohy, ktoré sa však v kontexte elitných detských hrobov z územia Slovenska objavujú len ojedinele. V súvislosti s vyjadrením vyššieho spoločenského statusu sledovanej doby sa častejšie stretávame s d'alším fenoménom - s vkladaním zbraní do detských hrobov. V našom prostredí ide výlučne o sekery, teda o exempláre rovnakých rozmerov, aké nachádzame v hroboch dospelých bojovníkov. V skúmanom súbore ich nachádzame v desiatich detských hroboch (čo je 0,38 \% z celkového počtu včasnostredovekých detských hrobov z územia Slovenska), z čoho vyplýva, že nejde o bežný jav. Navyše, napriek tomu, že spomínané atribúty bojovníka sú umiestnené vo funkčnej polohe, v tomto kontexte predstavujú „len“ symbolickú funkciu, teda majú za úlohu demonštrovat’ status dietat’a.

Šperky v detských hroboch 9. storočia tvoria pestrú a rozmanitú druhovú škálu, v niektorých prípadoch aj vo výraznom kvantitatívnom zastúpení. Ako príklad možno uviest' hrob 123 z pohrebiska v Čakajovciach, kde bolo pochované diet’a spolu s 15 záušnicami, troma bronzovými náramkami, nákrčníkom, prsteňom, piatimi sklenenými gombíkmi, liatymi dvojdielnymi gombíkmi a množstvom korálikov a d’alších súčastí náhrdelníka - mušle kauri a závesku z prevítaného jelenieho očného zuba (Rejholcová 1995, 13-14). Obzvlášt' zaujímavý, aj ked' mladší (zo záveru prvej polovice 10. storočia), je detský hrob 269 z toho istého pohrebiska. Diet’a vo veku 7-14 rokov bolo vybavené bohatým inventárom, ktorý aj v tomto prípade demonštruje status tu pochovaného jedinca (obr. 3; Rejholcová 1995, 29).

Elitné postavenie detí v predmetnom období nedokladá len bohatý inventár, ale podobne ako v predchádzajúcom časovom horizonte aj špeciálny pohrebný rítus. Na plochých pohrebiskách sa prejavuje špecifickou úpravou hrobu. Príkladom je drevená rakva vytesaná z jedného kusu z dievčenského hrobu 4 z pohrebiska v Blatnom, ktorý obsahoval aj bohatý inventár (Kraskovská 1966, 99). V tomto období možno prejav sociálnej diferenciácie sledovat' aj na mohylníkoch, nielen vd’aka zloženiu inventára, ale predovšetkým pomocou priestorového usporiadania hrobov a špeciálneho pohrebného rítu. Unikátny príklad tohto druhu predstavuje hrob chlapca z mohyly 12 z pohrebiska 
v Skalici (Budinský-Krička 1959, 12). Ten bol pochovaný $\mathrm{v}$ hrobe pod navýšeným mohylovým násypom, podobne ako dospelí bojovníci z predmetného pohrebiska, $v$ širokej hrobovej jame s hlavou podopretou dubovou doštičkou, ktorá bola vystlaná machom. Chlapec bol vybavený nožom, sekerou a dvoma strmeňmi. Okrem zmieneného hrobu sa na tejto nekropole nachádzali aj iné bohato vybavené detské hroby. Okrem honosnej výbavy a vnútornej úpravy hrobovej jamy drevom sa vyznačujú aj svojou špeciálnou lokalizáciou $\mathrm{v}$ rámci pohrebiska, pretože takmer všetky boli odkryté v juhozápadnej časti mohylníka (Budinský-Krička 1959, 12-13).

Napriek čoraz väčšej unifikácii hrobovej výbavy v závere včasného stredoveku možno ojedinele nájst' také detské hroby, ktoré sú špecifické bud' pohrebným rítom, alebo bohatým inventárom. Snád' najzaujímavejším z nich je hrob 78/06 na prikostolnom cintoríne v Kostol'anoch pod Tribečom (Baxa-Bisták 2009). Hrob patriaci dievčat'u (infans II.; Kolena-Luptáková 2009), situovaný v blízkosti Kostola svätého Juraja, obsahoval najbohatšiu výbavu zo všetkých skúmaných hrobov na cintoríne a zároveň jednu z najbohatších hrobových výbav pochádzajúcich z prikostolných cintorínov na Slovensku. V hrobe boli ako súčasti posmrtnej výbavy nájdené šperky a minca (Baxa-Polanský-Bisták 2006, 261). Zo šperkov si osobitnú pozornost' zaslúži náhrdelník pozostávajúci z 36 korálikov rôzneho materiálu (Staššíková-Štukovská-Hložek 2009). Ďalej sa v hrobe našiel strieborný štítkový prsteň a dve esovité záušnice. Ďalším nálezom z tohto hrobu je minca - denár Oldřicha I., interpretovaný ako obolus mŕtvych (Hunka 2009), ktorý výrazne prispel k spresneniu datovania hrobu, ako aj datovania výstavby murovaného kostola (Baxa-Bisták 2009).

Z vyššie načrtnutých informácií možno usudzovat', že jednotlivé spoločenstvá včasného stredoveku mali snahu poukázat' na dôležité postavenie detských jedincov prislúchajúcich vyššej vrstve spoločnosti, a tým demonštrovat’ ich konkrétne miesto v súvekých komunitách. V archeologickom materiáli sa to prejavuje analogickými javmi, ktoré možno sledovat' u dospelých elitných jedincov. Ide predovšetkým o špeciálnu úpravu hrobovej jamy, honosnú výbavu či výnimočné situovanie týchto hrobov v rámci pohrebiska. Aj vekové zastúpenie jedincov prezrádza, že i najmenšie deti boli právoplatnou súčastou spoločnosti a boli ňou rešpektované, čo sa odzrkadl'uje v jednotlivých prípadoch elitných detských pohrebov nielen na našom území. V súvislosti so skúmaným javom však zostáva nad’alej otvorená otázka ostatných, menej vybavených detských hrobov alebo tých bez výbavy. Z hl’adiska doterajšieho stavu archeologického bádania a bez interdisciplinárnej spolupráce je vo všeobecnosti hodnotenie sociálneho statusu detí vel'mi problematické a viac-menej sa obmedzuje len na skupinu vyššie hodnotených, elitných detských jedincov.

Určitý znak postoja dospelých voči svojim potomkom, resp. možný prejav záujmu a starostlivosti o deti, tentokrát bez ohl'adu na sociálne postavenie diet’at’a, možno sledovat' na základe špecifického hrobového inventára. V skúmanom súbore sa nachádzajú také detské hroby, ktoré obsahujú predmety s predpokladanou apotropajnou funkciou. Tie majú za úlohu dieta chránit' pred nepriaznivými silami, zlými duchmi alebo iným nešt’astím (napríklad Smetánka 1992, 189-191).

Do tejto skupiny možno, aj ked' len hypoteticky, zaradit' rol'ničky (obr. 4). Ich počet sa vo včasnostredovekých detských hroboch na území Slovenska obmedzuje na maximálne dva exem- 


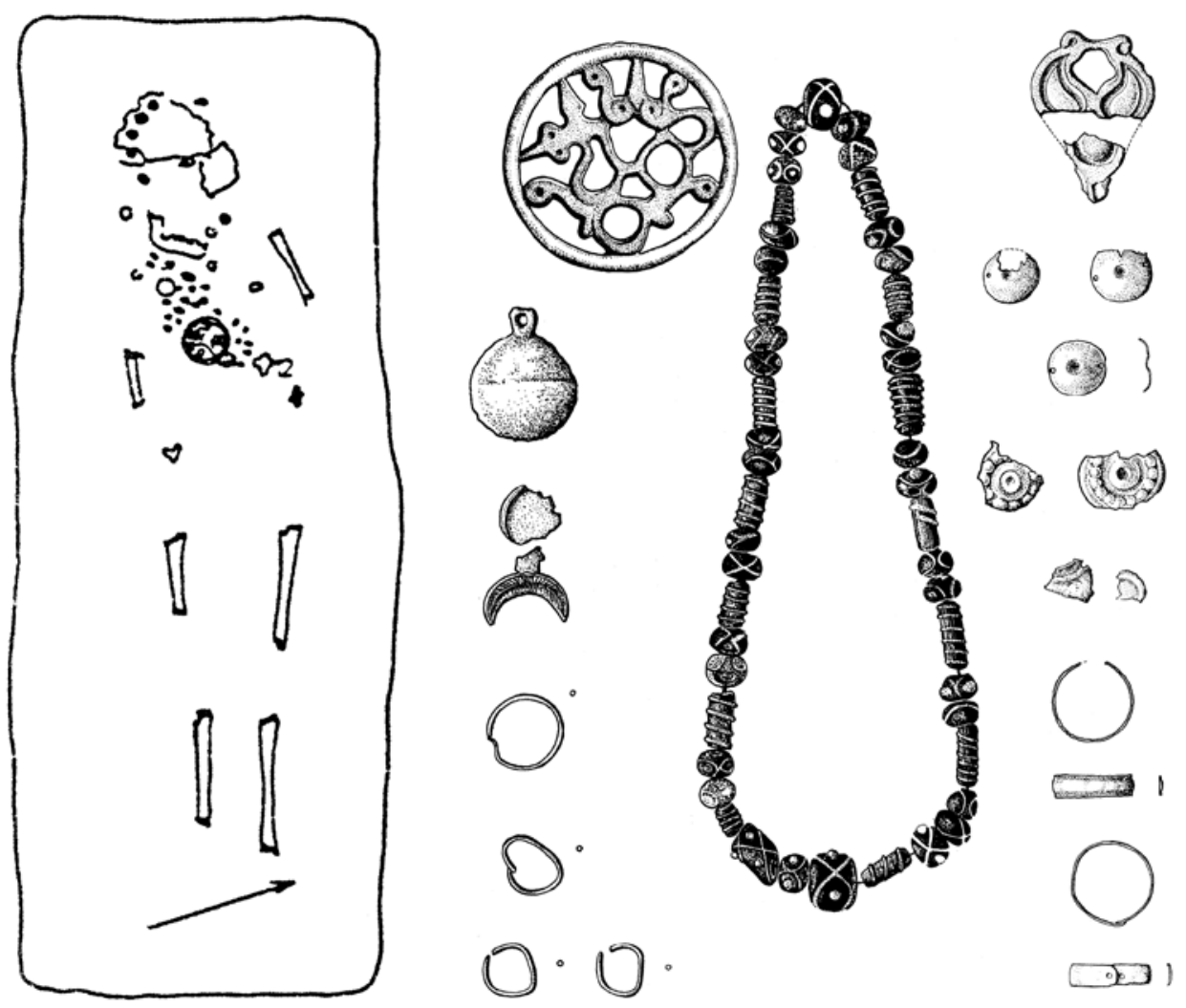

Obr. 3. Bohatá výbava detského hrobu 269 z pohrebiska v Čakajovciach. Podl’a Rejholcová 1995, tab. XLVII; CXXXI:4, upravené.

Abb. 3. Reiche Ausstattung von Kindergrab 269 vom Gräberfeld in Čakajovce. Nach Rejholcová 1995, Taf. XLVII; CXXXI:4, bearbeitet.

pláre v jednom hrobe, avšak nálezové celky s prítomnost’ou rol'ničky ako jediného milodaru nie sú tiež o nič vzácnejšie. V rámci jednotlivých etáp včasného stredoveku je zastúpenie hrobov obsahujúcich rol'ničky značne vyrovnané od obdobia avarského kaganátu po 11. storočie. Pri sledovaní faktora veku ako rozhodujúceho parametra v ukladaní rol'ničky do hrobu sa neprejavuje žiaden konkrétny vzorec. Zastúpenie v hroboch vekovej kategórie infans I. a infans II. je relatívne rovnocenné. Situácia je však značne skomplikovaná stavom bádania, ked' v hodnotenom súbore nebol určený vek až v prípade 19-tich hrobov s prítomnostou rol’ničky z celkového počtu 32. Ďalším aspektom, ktorý možno sledovat' pri výskyte rol'ničky, je sociálne postavenie. Z hodnotenia vyplýva, že ani tento aspekt neprinesie uspokojivé a jednoznačné výsledky. Výskyt rol'ničky je doložený jednak z hrobov elitne postavených detských jedincov, kde sa vo výbave vyskytuje s vel'kým množstvom šperku a d’alšími predmetmi deklarujúcimi vysoký sociálny status, ako i z hrobov bez d’alšej výbavy, kde tvorila jedinú prílohu. Najzaujímavejší nález rol'ničky pochádza z detského hrobu 175 z nekropoly z obdobia avarského kaganátu v Nových Zámkoch (Čilinská 1966, 37). Bolo v ňom pochované diet’a s rol'ničkou, ktorá bola zdobená štylizovanými l'udskými tvárami (obr. 4:1; Čilinská 1966, 278, Taf. XXXVI:7). Vel'mi pekným nálezom - jediným svojho druhu z územia Slovenska, je rol'nička z detského hrobu 208 z nekropoly z obdobia avarského kaganátu v Záhorskej Bystrici-Lokvy pri Morave (Kraskovská 1972, 40). Bola vyhotovená z bieleho kovu, mala hruškovitý tvar ukončený hranatým uškom a jej povrch bol zdobený fazetovaním (obr. 4:2). Rol’ničky sú vel’mi špecifickým prídavkom v hroboch detských jedincov. Primárne sa ich funkcia spája práve s ochranou, ktorú mal zabezpečovat’ ich 

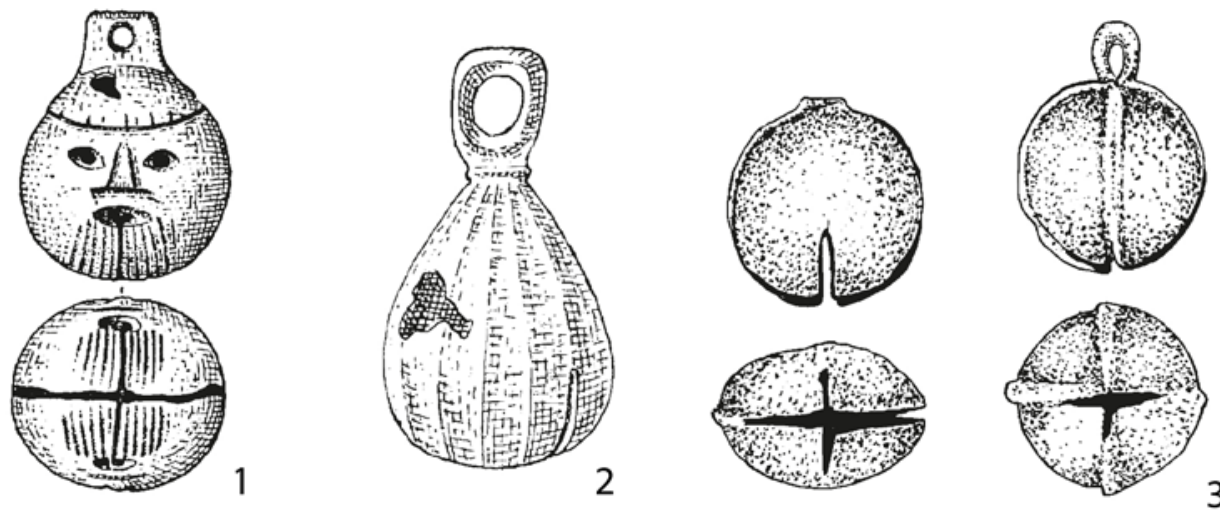

Obr. 4. Rol’ničky z detských hrobov. 1 - Nové Zámky. Podl’a Čilinská 1966, 278, Taf. XXXVI:7; 2 - Záhorská Bystrica. Podl’a Kraskovská 1972, 145, obr. 42:2; 3 - Komárno. Podl’a Trugly 1987, 312, Taf. XIII:19, 20.

Abb. 4. Glöckchen aus Kindergräbern. 1 - Nové Zámky. Nach Čilinská 1966, 278, Taf. XXXVI:7; 2 - Záhorská Bystrica. Nach Kraskovská 1972, 145, Abb. 42:2; 3 - Komárno. Nach Trugly 1987, 312, Taf. XIII:19, 20.

cinkavý zvuk (Eisner 1966, 428; Frölich-Chvojka-Michálek 2010, 211; Smetánka 2003, 12). Ďalším možným významom tohto zaujímavého predmetu je jeho praktická stránka, ked' mal zmienený predmet slúžit' ako signalizačné zariadenie, informujúce o pohybe diet'at'a v priestore (Csallányi 1966/1967, 72; Smetánka 2003, 16).

Apotropajná funkcia je pripisovaná i lunicovému závesku (obr. 5), ktorý je na základe svojho tvaru spájaný s mesačným kultom a s kultom plodnosti u žien (Eliade 1996, 163-169; Váňa 1988, 348). V prípade detských hrobov sa s prítomnostou lunicového závesku stretávame iba $\mathrm{v}$ deviatich nálezových celkoch, zastúpených vyrovnane v rámci celého trvania včasného stredoveku. Dievčenské pohlavie bolo s určitostou potvrdené iba v jednom prípade, avšak na základe výbavy z ostatných hrobov sa možno domnievat', že vo všetkých prípadoch išlo o jedincov ženského pohlavia. Najpozoruhodnejším z nich je hrob 229 z Nových Zámkov (Čilinská
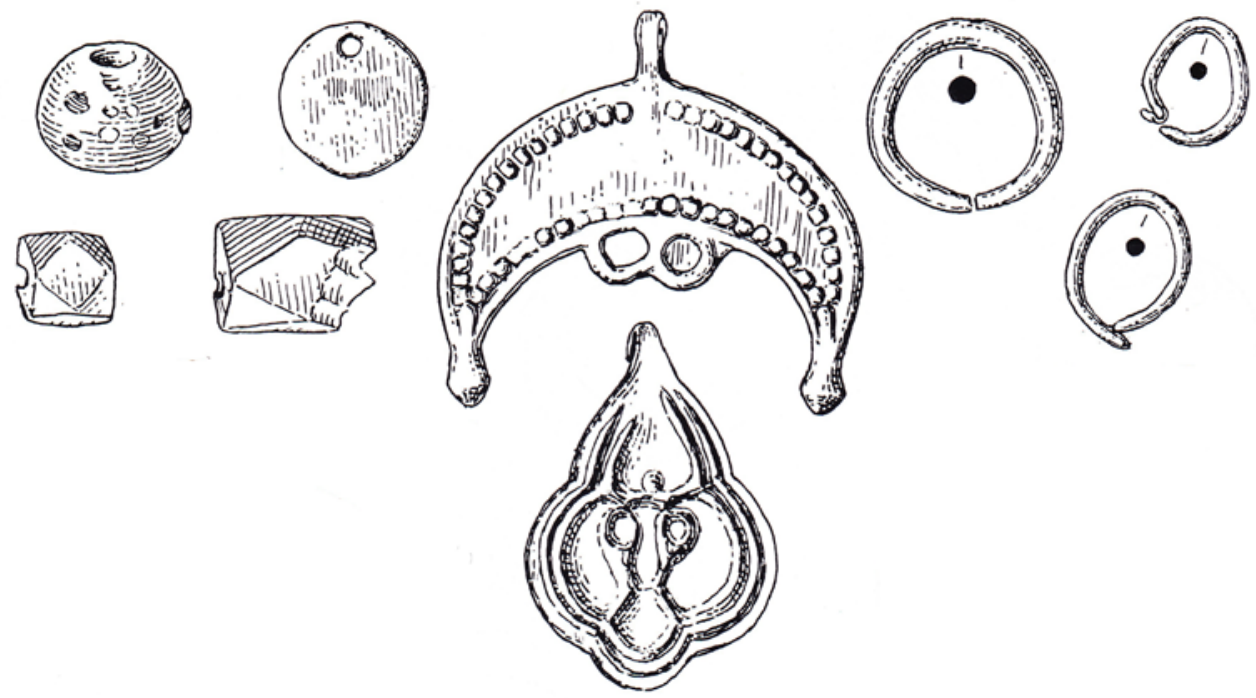

Obr. 5. Lunicový závesok a ostatný bohatý inventár detského hrobu 36 z pohrebiska v Hurbanove-Bohatej. Podl’a Rejholcová 1976, 224, Tab. V:36.

Abb. 5. Mondsichelförmiger Anhänger und sonstiges reiches Inventar aus Kindergrab 36 vom Gräberfeld in Hurbanovo-Bohatá. Nach Rejholcová 1976, 224, Taf. V:36. 
1966, 48), kde sa nachádzali fragmenty až troch lunicových príveskov. Interpretovat' ich význam je značne náročné, ked’že sa v období včasného stredoveku nevyskytujú vo vel'kom množstve (Chorvátová 1998, 135-136) a i samotný súbor hodnotených detských hrobov z územia Slovenska v pertraktovanom období s ich výskytom neposkytuje žiadne sumarizujúce znaky, ktoré by prispeli k určitým konkrétnejším výsledkom či hypotézam.

Rovnako ako lunicovým, i srdcovitým záveskom bola vo všeobecnosti pripisovaná apotropajná funkcia (Hanuliak 2004, 195). Ich nálezy nie sú obzvlášt' početné, rovnako ako v prípade lunicových záveskov. Pochádzajú z pohrebísk datovaných rámcovo do 9.-12. storočia a možno ich charakterizovat' ako typický šperk belobrdskej kultúry. V hroboch detí sa nachádzal často i s d’alšími predmetmi, ktorým je pripisovaný magický ochranný účinok (lunicové závesky, koráliky, mušle a pod.).

K vel’mi významným nálezovým celkom v kontexte sledovaných ochranných predmetov možno zaradit' ojedinelý hrob z 10. storočia z Tvrdošoviec, polohy Paptag (Točík 1992, 166). Diet’a $\mathrm{v}$ ňom bolo pochované $\mathrm{s}$ dvoma striebornými náušnicami a dvoma striebornými medailónmi zdobenými pätnásobnou hviezdicou. Okrem nich malo pravdepodobne na náhrdelníku zavesené ešte tri mušle kauri a striebornú prevítanú mincu s dvoma dierkami, datovanú do prvej polovice 9. storočia (obr. 6). Takmer všetok inventár v hrobe možno spájat' s predmetmi, ktorým sa pripisuje ochranná funkcia.

K predmetom s apotropajnou funkciou možno priradit' aj ojedinelý a vel'mi svojrázny nález hlineného vajca - „kraslice“, zdobený žlto-hnedou glazúrou, obsahujúci vo vnútri kamienok. Predmet pochádza z detského hrobu z pohrebiska datovaného do 11. storočia z Nitry-Dražoviec (Ruttkay 2005, 104). Napriek tomu, že pripomína hrkálky, teda duté uzavreté nádobky alebo hlinené figúrky s hrkajúcim obsahom (Měchurová 2010, 101), situovanie daného predmetu - na hrudi vo funkcii prívesku - vedie skôr k predpokladu o možnej ochrannej funkcii. Podobné predmety, ktoré by bolo možné spájat's hračkami vyskytujúcimi sa v ostatnom stredoeurópskom (aj širšom) priestore (Bukovčanová 2007; Hilczerówna 1950; Hoffmann 1996; Měchurová 2010; Schütte 1979; Smetánka 2003; Vachůt-Hladík 2010; Wawrzeniuk 2004) sa vo včasnom stredoveku na území Slovenska v detských hroboch zatial' neobjavili.

O možnej ochrannej funkcii v kontexte detských pohrebov môžu vypovedat' aj rôzne druhy korálikov, prevŕtané zvieracie zuby, rybie stavce a mušle, ktoré boli do detských hrobov vkladané s vyššie spomínanými predmetmi vo forme súčasti náhrdelníka (obr. 7). Netreba však zabúdat', že v detských hroboch mohli byt' prítomné aj iné formy amuletov, najmä rôzne druhy vyhotovené z organických materiálov, ktoré sa však do súčasnosti nemuseli zachovat'.

$\mathrm{Na}$ základe analýzy predmetov s možnou apotropajnou funkciou možno predpokladat', že ich charakter sa vyznačuje značne širokou škálou, rôznymi kombináciami, ktoré v hroboch nachádzame. Ich kvantitatívny, ako i kvalitatívny rozmer nás aspoň sčasti informuje o duchovnom svete minulých populácí́. Súvisí s rituálmi, ktoré archeologicky vieme zachytit' len vel'mi t'ažko, nehovoriac o pochopení ich samotnej podstaty. $Z$ tohto dôvodu je náročné ich bližšie interpretovat' aj v kontexte $\mathrm{s}$ ich výskytom v detských hroboch. V tejto súvislosti môžu slúžit' ako určitá priama indícia, ktorá nám trochu približuje vnímanie detských členov spoločnosti. Zároveň ju môžeme

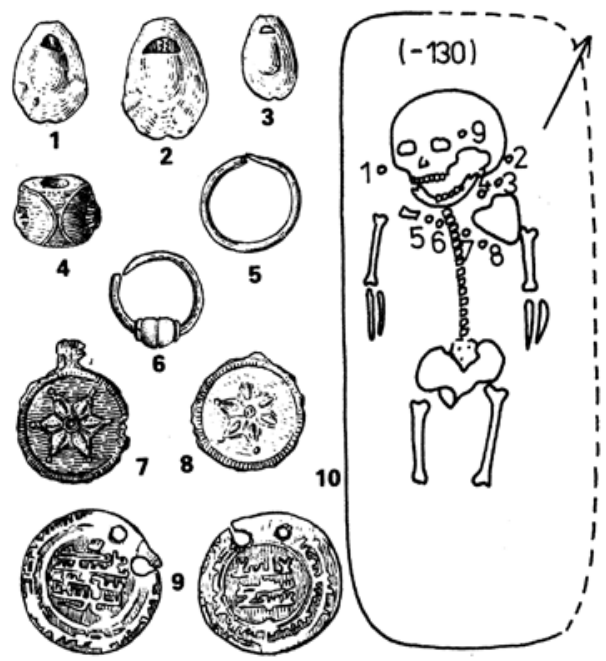

Obr. 6. Detský hrob so zaujímavým inventárom. Podl'a Točík 1992, 166, obr. 112.

Abb. 6. Kindergrab mit interessantem Inventar. Nach Točík 1992, 166, Abb. 112. 
chápat' ako doklad záujmu, pozornosti, ako aj starostlivosti rodičov o svoje diet’a.

V súvislosti s danou problematikou môžeme prostredníctvom archeologických prameňov postrehnút' d’alšie vel'mi zaujímavé javy, ktoré poskytujú svedectvo o postavení detí, resp. diet'at'a v konkrétnej komunite $\mathbf{v}$ danom čase i priestore. Ked'že ide o úkazy špecifické pre onú dobu, súčasníkovi ponúkajú skôr viacero možností hypotéz a domnienok, než konkrétne vysvetlenie.

K uvedeným javom možno zaradit' práve pochovávanie detských jedincov solitérne v hrobových jamách na sídliskách. Príkladom sú dva detské hroby zo sídliska z 9. storočia v Čataji, poloha Nad korytom (Hanuliak-Ožd'áni 2004, 35-36) a detský hrob z ned’alekého súdobého sídliska v Igrame, poloha Plynovod (Hanuliak-Ožd’áni 2004, 37). Za d’alšiu lokalitu s podobným javom možno považovat' sídlisko z 9.-12. storočia v Mužle-Čenkove, kde sa stretávame s detskými hrobmi situovanými za okrajové línie skupín sídliskových objektov (Hanuliak-Kuzma-Kolena 2012). Tieto detské pohreby sa svojimi atribútmi neodlišovali od bežných hrobov na občinových nekropolách, avšak samotný fakt, že boli vyčlenené z areálu pochovávania, napovedá, že nastali nezvyčajné okolnosti, ktoré prinútili danú komunitu detské hroby odčlenit'. Mohlo dôjst' k porušeniu zvyklostí a noriem danej komunity, alebo išlo o detských jedincov s nižším sociálnym statusom bez bližších väzieb k ostaným členom komunity (Hattenhauer 1998, 9-10; Šolle 1966, 129).

Podobne t’ažko sa interpretujú aj hroby s detskými jedincami nepietne pochovanými v sídliskových objektoch. Príkladom je zásobná jama 438 zo sídliska v Mužle-Čenkove, poloha Vilmakert (Hanuliak-Kuzma-Šalkovský 1993), v ktorej bolo pochované 10-11-ročné diet’a (obr. 8; Hanuliak-Kuzma-Šalkovský 1993, 157; Hanuliak 1997, 162, obr. 4:4). Ďalšie detské skelety v podobnej situácii na tomto sídlisku pochádzajú aj z dvoch d’alších objektov (Hanuliak 1997, 161, 164, obr. 5:1). Samotné pohreby nevykazujú znaky pietneho pochovania. Kostry detí skôr budia dojem, že boli do sídliskových jám hodené, resp. ich pohrebu nebola venovaná rituálnost', ktorú badat' v pietnych detských pohreboch na ostatných nekropolách v sledovanom období.

Ďalším špecifikom sú detské hroby umiestnené na periférii pohrebísk. Jedným z nich je nekropola z 9. storočia v Nitre-Lupke (Chropovský 1962), kde boli vyčlenené skupiny pohrebov detí podl'a veku. Podl'a plánu pohrebiska sa detské hroby nachádzajú predovšetkým v okrajových, menej prestížnych zónach vyčlenených hrobových areálov. V súbore sa nenachádzali iba 
samostatné hroby detí, ale aj dvojhroby, poprípade trojhroby, v ktorých boli deti pochované s dospelou osobou. Princíp rozmiestnenia hrobov bol dodržiavaný aj napriek tomu, že centrálny priestor vyčlenených štyroch skupín nebol zaplnený hrobmi (Hanuliak 2006, 177). Podobnú zásadu usporiadania hrobov možno sledovat' aj vo vyčlenenej tretej skupine hrobov na pohrebisku v Bučanoch a v prvej a druhej skupine na pohrebisku vo Svätom Petri (Hanuliak 2006, 276, obr. 13, 278, obr. 15). V tomto prípade môže íst' o hroby detí, ktoré ešte nestihli prejst' rituálom dospelosti, a preto im bol vyčlenený samostatný areál zodpovedajúci ich postaveniu a vnímaniu komunitou pochovávajúcou na danej nekropole. Umiestnenie na pohrebisku však môže vypovedat' i vel'mi konkrétne o vnímaní detí, ako je tomu v prípade už spomínaného mohylníka v Skalici, kde bola vyčlenená čast' pre elitne pochovaných detských jedincov.

V súvislosti s pohrebiskom v Nitre-Lupke boli spomenuté hroby detí, ktoré sú pochované spolu s inými jedincami. Ide o špecifický jav, s ktorým sa stretávame od obdobia avarského kaganátu až po koniec včasného stredoveku. V skúmanom súbore evidujeme 87 dvoj-, desat’ trojhrobov a jeden štvorhrob, čo spolu tvorí 3 \% z celkového analyzovaného počtu detských hrobov zo včasného stredoveku na Slovensku. Najčastejšiu kombináciu predstavuje pohreb ženy s jedným (28 prípadov), menej s dvoma det’mi (5 hrobov). Tie sú uložené väčšinou v rovnakej orientácii, v prevažnej väčšine na hrudi, menej často v mieste panvy, pri nohách ženy (matky?) alebo vedl'a nej (obr. 9). Menej početnú kategóriu predstavujú viachroby detí s mužským jedincom. Dvojhrob v kombinácii muža s diet’atom sa v skúmanom súbore vyskytuje 13krát, muža s dvoma det'mi $v$ dvoch prípadoch a dvoch mužov a jedného diet’at’a $v$ jednom prípade. Umiestnenie detského skeletu je rovnaké ako v prípade pochovanej ženy a detí. V rámci skupiny dvojhrobov sa stretávame aj s kombináciou dvoch detských jedincov. V skúmanom súbore evidujeme 24 takých hrobov, pričom vo väčšine prípadov boli deti v nich uložené v natiahnutej polohe, jedno vedl'a druhého s rovnakou orientáciou. Zaujímavý z hl'adiska lokalizácie skeletov je dvojhrob 121 z pohrebiska z obdobia avarského kaganátu z Radvane nad Dunajom (Točík 1992, 52), v ktorom boli deti uložené nohami oproti sebe do uhlopriečky (obr. 10). Deti natočené chrbtami k sebe pochádzajú z dvojhrobu 163 z nekropoly v Trnovci nad Váhom-Remízke (Točík 1971, 150). Poslednú výnimočnú polohu v rámci detských skeletov predstavuje dvojhrob 668 z nekropoly z obdobia avarského kaganátu v Želovciach (Čilinská 1973, 152-153), v ktorom sa kostrička novorodenca nachádzala pri pravom stehne staršieho diet’at'a.

V súvislosti s vyššie opísaným fenoménom v pohrebnom ríte je nutné sa zamysliet' nad príčinami spolupochovávania detí s inými členmi komunity. Jedným z možných dôvodov by mohli byt' pokrvné väzby takto pochovaných jedincov, teda diet’a s rodičom alebo diet'a so súrodencom. Dokladom tejto hypotézy by mohli byt' výsledky antropologických analýz, ktoré však na našom území doposial' výrazne absentujú. V tomto smere musíme zatial' vychádzat' predovšetkým z archeologických prameňov. Prostredníctvom nich možno predpokladat' príbuzenský zväzok pochovaných detí vo viachrobe na základe viacerých zistení. Jedným z nich je vzájomné uloženie pochovaných jedincov, ktoré v mnohých prípadoch zahíňa natočenie hláv k sebe, poprípade ovinutie rukou symbolizujúce objatie, ako je tomu v dvojhrobe 47 ženy a diet’at’a z Nitry-Lupky (Chropovský 1962, 188), či poloha vzbudzujúca dojem objímajúceho diet’at’a v dvojhrobe 774 v Holiaroch (obr. 9; Točík 1968, 113, Abb. 35). Dojímavým prípadom je jediný štvorhrob z hodnoteného súboru, pochádzajúci z kostolného cintorína v Martine. Pochovaní sú v ňom žena a muž s prepletenými rukami a hlavami otočenými k sebe. Pri nohách týchto dospelých sú v natiahnutej polohe uložené kostry dvoch detských jedincov (Budinský-Krička 1944, 24).

Interpretáciu príbuzenského (rodičovského) vzt’ahu ešte viac umocňujú hroby žien s det'$\mathrm{mi}$ - novorodencami, ktorých skelety sú situované do blízkosti panvy pochovanej ženy, napríklad trojhrob 672 z Čakajoviec (Rejholcová 1995, 75); trojhrob 386 z Nových Zámkov (Čilinská 1966, 75-76); trojhrob 51 z Nitry-Lupky (Chropovský 1962, 189). S istotou môžeme definovat' hroby matiek s det'mi, ktoré sa nachádzali ešte $\mathrm{v}$ intrauterinnom vývine a ich matka zomrela bud' počas pôrodu, alebo na komplikácie počas tehotenstva. Zmienený prípad predstavuje trojhrob 19 v Nitre-Lupke, kde bola pochovaná dospelá žena s malým diet’atom umiestneným v oblasti jej hrude a s d’alším, ešte nenarodeným diet’atom. Pochovaná žena zomrela pri jeho pôrode (Chro- 
povský 1962, 181). Podobnú situáciu predstavuje i hrob č. 157 z Košíc-Šebastoviec. Bola v ňom pochovaná žena, dospelá osoba vekovej kategórie adultus II., a dvojičky v 10. mesiaci vnútromaternicového vývinu (Budinský-Krička-Točík 1991, 37).

V ostatných prípadoch musíme pripustit' aj iné možné príčiny tohto špecifického javu. Etnografické paralely z územia Afriky dokladajú, že dvojhroby dospelých s novorodencami môžu byt’ vyjadrením sociálneho statusu a zároveň aj bezpečného prechodu na druhý svet, či záruky spokojného posmrtného života, ktoré malo sprostredkovat' práve diet’a (napríklad Čilinská-Wolska 1979, 148; Ďuricová 2012, 135). Do tejto interpretačnej roviny by sme mohli zaradit' hrob 58 z pohrebiska v Šebastovciach (Budinský-Krička-Točík 1991, 17), kde bolo spolu s jazdcom pochované po jeho pravej strane aj šest'ročné diet’a vo vystretej polohe. Podobná situácia je doložená aj v trojhrobe 22 z nekropoly v Komárne-Hadovciach (Čilinská 1982, 361), v ktorom bol pochovaný jazdec a na jeho hrudi a pri nohách sa nachádzala detská lebka. Nezvyčajnú situáciu

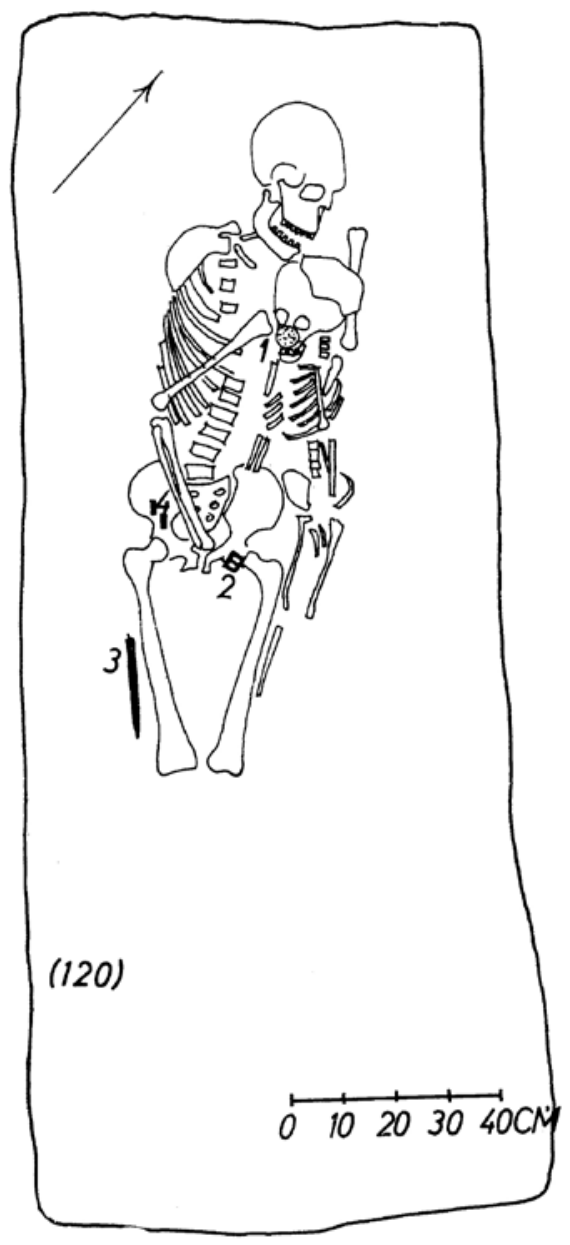

Obr. 9. Dvojhrob 774 z pohrebiska v Holiaroch: žena s rukou ovinutou okolo diet'at'a spočívajúceho na hrudi ženy/ matky (?). Podl'a Točík 1968, 113, Abb. 35.

Abb. 9. Doppelgrab 774 vom Gräberfeld in Holiare: Frau mit um ein Kind gelegtem Arm, das an der Brust der Frau/ Mutter (?) ruht. Nach Točík 1968, 113, Abb. 35.

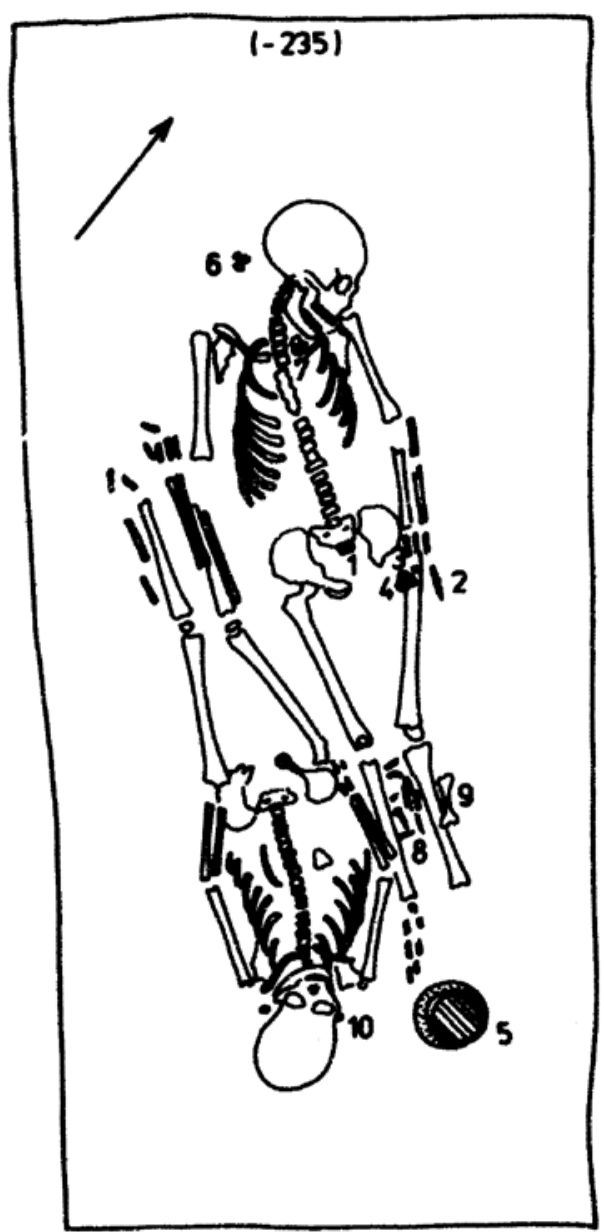

Obr. 10. Dvojhrob 121 z pohrebiska v Radvani nad Dunajom: dve deti uložené nohami oproti sebe do tvaru uhlopriečky. Podl'a Točík 1992, 64, obr. 28:5.

Abb. 10. Doppelgrab 121 vom Gräberfeld in Radvan̆ nad Dunajom: zwei mit den Beinen diagonal entgegengesetzt bestattete Kinder. Nach Točík 1992, 64, Abb. 28:5. 
predstavuje aj hrob 1 z lokality Žitavská Tôň (Čilinská 1963, 87), kde bol spolu s dvoma jazdcami pochovaný aj novorodenec.

Pri otázke pochovania dvoch detí do jedného hrobu sa taktiež naskytuje niekol'ko možných odpovedí. Ak vezmeme do úvahy, že deti, najmä do prvých šest' rokov, predstavovali najrizikovejšiu skupinu a boli najnáchylnejšie na rôzne infekčné ochorenia, možno následne uvažovat' o súčasnej smrti viacerých detských jedincov v dôsledku fatálnej choroby.

Ďalší problematický jav z hl'adiska interpretácie, s ktorým sa stretávame pri hodnotení detských hrobov, je prítomnost' predmetov dennej potreby (obr. 11). V tejto súvislosti sa naskytá otázka symbolického významu zmienených predmetov pri určovaní primárnych úloh detí v každodennom živote.

Jedným z najfrekventovanejších artefaktov je nôž, ktorý sa v sledovanom súbore objavuje v 372 detských hroboch oboch vekových kategórií (infans I. aj infans II.) od obdobia avarského kaganátu po 9. storočie. Poloha noža v hroboch je značne variabilná. Nachádza sa na rôznych pozíciách pozdĺž kostry diet’ata. Napriek tomu, že ho najčastejšie evidujeme v prítomnosti d’alších milodarov, v skúmanom súbore sú hroby, kde bol jediným prídavkom. Okrem toho poznáme aj také detské hroby s prítomnost'ou noža, ktoré na základe ostatného inventára poukazujú na vyšší sociálny status pochovaného jedinca (napríklad mohylník v Skalici; Budinský-Krička 1959, 13).

Ďalším, avšak menej častejším milodarom je praslen, vyskytujúci sa vo včasnostredovekých detských hroboch na území Slovenska v 56 prípadoch prevažne z obdobia avarského kaganátu. Prítomnost' praslena je takmer vo všetkých hroboch v kombinácii s d’alšími predmetmi. Často sa vyskytuje v detských hroboch spolu so šperkmi, súčast’ami opaskovej garnitúry, keramikou, zvieracími kost’ami a vaječnými škrupinami. Minimum nálezových celkov tvoria hroby, kde praslen predstavoval jediný milodar. Prasleny sa objavujú v hroboch batoliat, menších, ako aj väčších detí oboch pohlaví.

Podobnú situáciu, avšak len v sporadickom zastúpení, možno sledovat' aj v súvislosti s prítomnost'ou ostatných predmetov dennej potreby - nožníc, vedierok, ihelníkov, ihiel a šidiel v detských hroboch.

Ďalšiu skupinu predmetov v detských hroboch predstavujú pracovné nástroje. Do tejto kategórie možno zaradit' aj pol'nohospodárske náradie. V detských hroboch zo sledovaného územia sa vyskytuje len vel'mi ojedinele. Doposial' evidujeme len pät' kosákov, jednu radlicu a jednu motyku (Borzová 2016, 113). S výnimkou kosáka z detského hrobu 3 v Rovinke (Němejcová-Pavúková 1962, obr. 225:3), ostatné pol'nohospodárske náradie z hrobov detí sa nelíši od exemplárov vyskytujúcich sa v hroboch dospelých jedincov (Borzová 2006, 216). Objavujú sa v hroboch detí

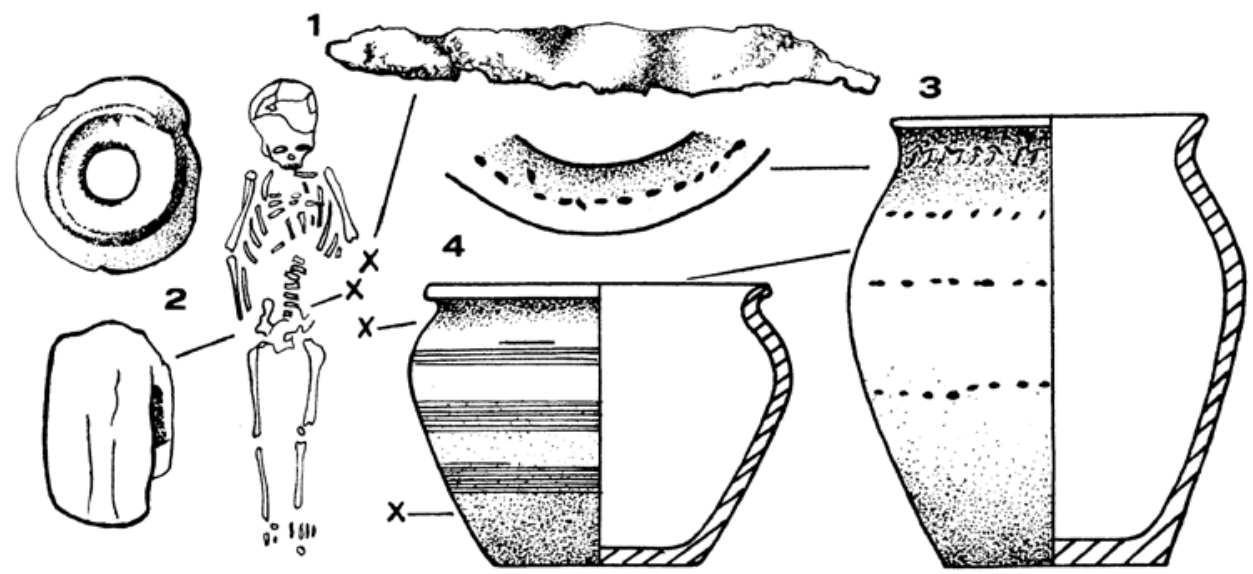

Obr. 11. Predmety dennej potreby v detskom hrobe 80 z pohrebiska na Devíne. Podl’a Plachá-Hlavicová-Keller $1990,57$. Abb. 11. Gegenstände des täglichen Gebrauchs in Kindergrab 80 im Gräberfeld von Devín. Nach Plachá-Hlavicová-Keller 1990, 57. 
oboch pohlaví (výnimočne aj v dvojhroboch; Zábojník 2004, 103), rôzneho veku a sociálneho postavenia. Väčšinou sú uložené v mieste hlavy, horných končatín alebo na hrudníku.

Predmety dennej potreby a pracovné nástroje v detských hroboch, ako to vyplýva z vyššie načrtnutých výsledkov analýzy, nemôžeme chápat' ako predmety v kontexte reálneho využitia počas života, ani ako odraz každodenných aktivít diet’ata. V mnohých prípadoch sa zmienené artefakty nachádzali v hroboch novorodencov, dojčiat a vel'mi malých detí, dokonca aj v elitných detských hroboch, ked' sa celá interpretačná rovina z archeologického hl'adiska mení. Tu vyvstáva otázka, prečo boli predmety do detských hrobov pridávané, aká bola ich funkcia, poprípade, či mali hlbší, symbolický význam, ktorý doposial' nedokážeme postihnút'.

Prostredníctvom archeologického bádania možno postihnút' aj také prejavy pohrebného rítu, ktoré u súčasníka evokujú pocit nehumánneho zaobchádzania s detskou čast’ou populácie včasného stredoveku. Nemožno však zabúdat', že „stredoveký človek“ a jeho pohl’ad na svet sa diametrálne líšil od nášho. Preto nižšie analyzované prejavy treba chápat' nie vždy ako negatívne, skôr ako výpoved' o určitom spôsobe upozornit' na detského jedinca v danej spoločnosti.

Špecifický postoj voči detským jedincom môžu reflektovat' nepietne pohreby. V takomto prípade boli deti pochované $\mathrm{v}$ abnormálnej polohe, ktorá indikovala násilné zásahy na ich tele. Detskí jedinci boli pochovaní na bruchu, v sediacej polohe, na l’avom či pravom boku a s rôznymi odchýlkami uloženia horných i dolných končatín (graf 4).

Najčastejšia poloha tela takto pochovaných detí je vystretá alebo skrčená na pravom či l’avom boku. Našli sa však aj prípady, ked' je diet’a pochované vo vel'mi neobvyklej polohe. Jedným z nich je aj ojedinelý hrob, datovaný do obdobia avarského kaganátu z Kubáňova (Béreš 1977, 55-56), ked' diet’a ležalo vo vystretej polohe na bruchu s hlavou smerujúcou na juh. Doteraz sa $\mathrm{v}$ publikovanom včasnostredovekom materiáli nenašla analógia $\mathrm{k}$ takémuto nezvyčajnému detskému pohrebu. Kostra z hrobu 11 z vel'komoravského pohrebiska v Devíne, poloha Staré vinohrady (Kraskovská 1963, 394), vzbudzuje dojem, že diet’a bolo nepietne pohodené do hrobu, ktorý rozmermi jasne napovedá, že bol vykopaný pre dospelú osobu. Za d’alší prípad možno považovat' deti pochované v takmer sediacej polohe. Jedným z nich je i hrob 350 z nekropoly z obdobia avarského kaganátu v Košiciach-Šebastovciach (Budinský-Krička-Točík 1991, 68). V hrobe bol pochovaný vel'mi malý, asi dvojročný jedinec.

$\mathrm{K}$ najčastejším intencionálnym zásahom na detských kostrách patria výrazne pokrčené nohy a v lakt’och zohnuté ruky, ktoré sa spájajú so skrčeným spôsobom uloženia tela. Uvedené zásahy možno badat' na detských kostrách z hrobu 144 z pohrebiska z obdobia avarského kaganátu v Štúrove, poloha Vojenské cvičisko (obr. 12; Točík 1968a, 43), či z hrobu 5 z vel'komoravského pohrebiska v Bojničkách (Bialeková 1993, 226-227). Posledný hrob je zaujímavý už len z toho dôvodu, že aj ked' kostra jedinca napovedá o jeho nepietnom pochovaní, všetky

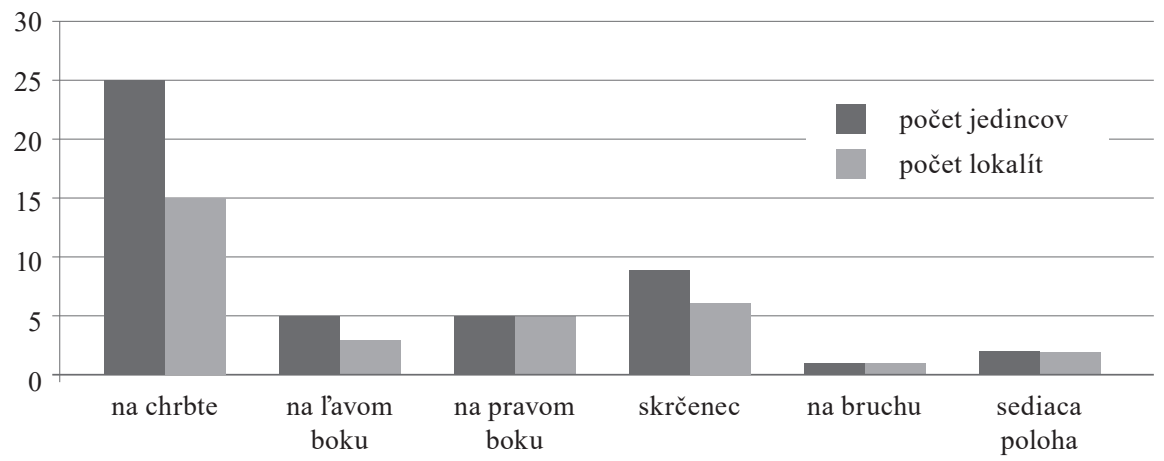

Graf 4. Poloha tela neštandardne pochovaných detských jedincov.

Diagramm 4. Körperlage von nicht standardgemäß bestatteten Kinderindividuen. 
ostatné atribúty spájané s pietnym pohrebom boli zachované. Pochovaný, pravdepodobne chlapec, bol vybavený predmetmi s vysokou ekonomickou, v tomto prípade najmä symbolickou hodnotou. Medzi jeho chodidlami sa nachádzala ostroha a okrem nej aj železný nôž a po dve nákončia a prevliečky. Na základe hrobového inventára možno uvažovat' o príslušnosti jedinca k vyššej sociálnej vrstve, pravdepodobne mohol byt' potomkom niektorého z členov bojovníckej družiny, pochovaného na pohrebisku.

Archeologické pramene týkajúce sa „detských nepietnych hrobov" nie sú dostatočne priamočiare a zrejmé $\mathrm{v}$ kontexte interpretácie a neposkytujú potrebné informácie $\mathrm{k}$ bližšiemu pochopeniu podstaty tohto fenoménu $\mathrm{v}$ rámci pohrebného rítu. $\mathrm{Z}$ ich obsahu vyplýva záver, že skupina 69 detských jedincov nie je zo sociálneho hladiska ničím výnimočná a hroby tohto druhu sa bežne nachá-

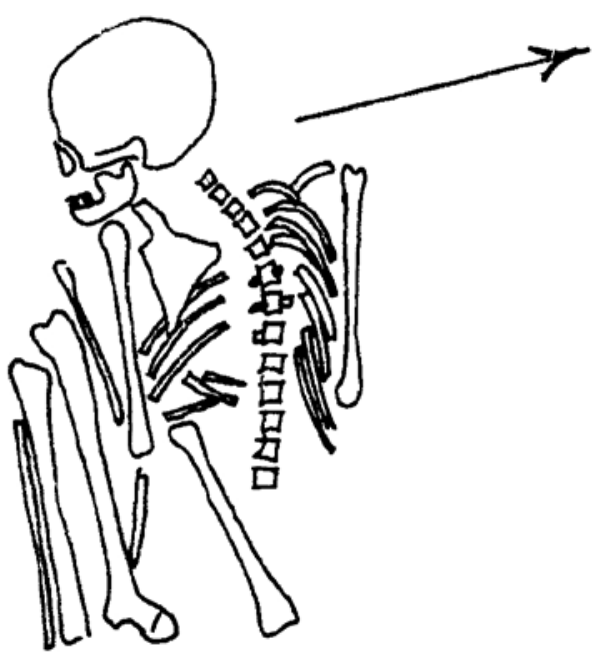

Obr. 12. Nepietne pochovanie diet'at'a v hrobe 144 na pohrebisku v Štúrove. Podl'a Točík 1968a, 84, Taf. VIII:4.

Abb. 12. Würdelos bestattetes Kind in Grab 144 auf dem Gräberfeld in Štúrovo. Nach Točík 1968a, 84, Taf. VIII:4. dzajú na nekropolách $\mathrm{v}$ rámci takmer celého včasného stredoveku, s upadajúcim trendom výskytu $\mathrm{k}$ jeho koncu. $\mathrm{V}$ hroboch neštandardne pochovaných detských jedincov sa stretávame výnimočne i s predmetmi s nadpriemernou ekonomickou hodnotou. Bežne sú to však predmety nehodnotné, poprípade hroby úplne bez nálezov. Priestorové umiestnenie takýchto hrobov nevykazuje žiadne výraznejšie odchýlky. Boli najčastejšie umiestňované bez špecifickejšieho systému medzi ostatných pochovaných jedincov. Úprava hrobových jám neindikuje výrazné odlišnosti, či už v prípade jej tvaru, rozmerov alebo híbky. Častokrát boli deti pochované v jamách bez zretel’nejších obrysov. Vek detí takisto nepredstavuje faktor, ktorý by ozrejmil selekciu jedincov so „špeciálnymi“ črtami. Antropologické analýzy nepriniesli informácie o detských kostrách s výnimočnými anomáliami a zásahmi, ktoré by svedčili o špeciálnom postavení jedinca v spoločnosti, dôsledkom ktorého by mohli byt’ špecifické opatrenia. Jednotlivé úkony slúžiace k imobilizácii a uväzneniu jedinca v hrobe vykazovali značnú pestrost'. Z toho dôvodu nemožno hovorit' o preferovaní určitého druhu imobilizácie výlučne u detí, ktorá by sa odlišovala od spôsobov vykonávaných na kostrách dospelých jedincov.

Vyššie opísané elementy pohrebného rítu, ako aj hrobová výbava detských jedincov vypovedajú o viacerých javoch, ktoré poukazujú na svet detí vo včasnom stredoveku, presnejšie povedané, prezentujú vnímanie a postoj konkrétnej komunity k detom. V širšom ponímaní nás zároveň informujú aj o duchovnom svete a predstavách človeka v sledovanom období. Zmienené fenomény spájané s detským svetom, akými sú napríklad starostlivost' a ochrana detí, sa vyskytujú aj v súčasnosti. Preto ich, napriek inému prejavu v sledovanom období, vieme chápat' a sčasti aj interpretovat'. Na druhej strane, prostredníctvom analýzy archeologického materiálu sa stretávame s takými prejavmi v súvislosti s nazeraním na detský život a postavenie detí v spoločenstve, ktoré v našich očiach nemusia byt' pochopitel'né, avšak pre minulé komunity mali špecifický a duchovný rozmer. Z dôvodu ich (ne)pochopenia je vhodné čerpat' a vychádzat' aj z iných prameňov, ako len z archeologického materiálu. Ide predovšetkým o písomné pramene, dobové vyobrazenia, ako aj etnografické paralely či antropologické a paleodemografické analýzy. To je však výzva pre d’alší príspevok na danú tému. 


\section{Pramene a literatúra}

BAXA, P.-BISTÁK, P., 2009: Prvé výsledky revízneho archeologického výskumu cintorína pri Kostole sv. Juraja v Kostol'anoch pod Tribečom, Monumentorum Tutela 21, 53-64.

BAXA, P.-POLANSKÝ, L.-BISTÁK, P., 2006: Př́́spěvek k česko-uherským kontaktům na přelomu 10. a 11. století. Hrobový nález denáru Oldřicha I. (1012-1033, 1034) v Kostol'anoch pod Tribečom. In: Numismatický sborník, 260-265. Praha.

BÉREŠ, J., 1977: Včasnostredoveké hrobové nálezy z juhozápadného Slovenska, Archeologické výskumy a nálezy na Slovensku v roku 1976, 55-59.

BIALEKOVÁ, D., 1993: Slovanské pohrebisko v Bojničkách, ŠZ AÚ SAV 29, 223-258.

BORZOVÁ, Z., 2006: Kosáky v hroboch z obdobia včasného stredoveku na Slovensku, S1Arch LIV, 209-237. - 2016: Pol'nohospodárske náradie včasného stredoveku na Slovensku. Nitra.

BUDINSKÝ-KRIČKA, V., 1944: Prvé staroslovenské radové pohrebištia v Turci a v Liptove: Prvé nálezy staroslovenských radových pohrebíšt' hradištných na Strednom Slovensku. Martin.

- 1959: Slovanské mohyly v Skalici: Slawische Hügelgräber in Skalica. Bratislava.

BUDINSKÝ-KRIČKA, V.-TOČÍK, A., 1991: Šebastovce. Gräberfeld aus der Zeit des awarischen Reiches: Katalog. Nitra.

BUKOVČANOVÁ, E., 2007: Hry a zábavy v stredoveku. Nepublikovaná diplomová práca, Katedra archeológie FF UK v Bratislave.

BUTLER, J., 1990: Gender trouble: feminism and the subversion of identity. London.

CSALLÁNYI, D., 1966/1967: Sámáneszköz volt-e az avarkori „írtartó csonttégely“?, Móra Ferencz Múzeum Évkönyve 1, 61-72.

ČILINSKÁ, Z., 1963: Slovansko-avarské pohrebisko v Žitavskej Tôni, SlArch XI, 87-120.

- 1966: Slawisch-awarisches Gräberfeld in Nové Zámky. Bratislava.

- 1973: Frühmittelalterliches Gräberfeld in Želovce. Bratislava.

- 1982: Dve pohrebiská z 8.-9. storočia v Komárne, SlArch XXX, 347-393.

ČILINSKÁ, Z.-WOLSKA, W., 1979: Štrukturálna a demografická analýza včasnohistorického pohrebiska v Želovciach, SlArch XXVII, 139-164.

ĎURICOVÁ, M., 2012: Pohrebný rítus na pohrebiskách obdobia avarského kaganátu na Slovensku. Nepublikovaná dizertačná práca, Katedra archeológie FF UK v Bratislave.

EISNER, J., 1966: Rukovět' slovanské archeologie. Praha.

ELIADE, M., 1996: Patterns in Comporative Religion. Nebraska.

FRÖLICH, J.-CHVOJKA, O.-MICHÁLEK, J., 2010: Nálezy rolniček v jižních Čechách, AVJČ 23, $205-220$.

GILCHRIST, R., 1991: Women's Archaeology? Political feminism, gender theory and historical revision, Antiquity 65, 495-501. DOI 10.1017/S0003598X00080091

HANULIAK, M., 1997: K problematike skeletov l'udských jedincov zo sídliskových objektov, SlArch XLVII, 157-182.

- 2004: Vel'komoravské pohrebiská: Pochovávanie v 9.-10. storočí na území Slovenska. Nitra.

- 2006: Detskí jedinci vo vel'komoravskom prostredí na základe pohrebiskových prameňov z územia Slovenska, SlArch LIV, 259-284.

HANULIAK, M.-KUZMA, I.-KOLENA, B., 2012: Kategorizácia jedincov pochovaných v opevnenom sídlisku z 9.-10. storočia v Mužle-Čenkove, SbNM A 66, 71-79.

HANULIAK, M.-KUZMA, I.-ŠALKOVSKÝ, P., 1993: Mužla-Čenkov I: Osídlenie z 9.-12. storočia. Nitra.

HANULIAK, M.-OŽĎÁNI, O., 2004: Vel'komoravské hroby zo sídliskového areálu v Čataji a Igrame, ŠZ AÚ SAV 36, 35-48.

HATTENHAUER, H., 1998: Evropské dějiny práva. Praha.

HILCZERÓWNA, Z., 1950: Przyczynki do handlu Polski z Rusit Kijowska, Przegląd Archeologiczny 9, 8-23.

HOFFMANN, V., 1996: Allerlay kurtzwei - mittelalterliche und frühneuzeitliche Spielzeugfunde aus Sachsen, Arbeits- und Forschungsberichte zur sächsischen Bodendenkmalpflege 38, 127-200.

HUNKA, J., 2009: Numizmatický a historický význam mincí objavených pri výskume Kostola sv. Juraja, Monumentorum Tutela 21, 65-71.

CHORVÁTOVÁ, H., 1998: K významu lunicových príveskov z včasnostredovekých pohrebísk strednej Európy, Praehistorica 23, 135-140.

- 2009: Podoby rodiny v ranom stredoveku, Studia Christiana 5, 140-151.

- 2012: Deti a detstvo vo včasnom stredoveku, Documenta Pragensia XXXI, 49-72.

CHROPOVSKÝ, B., 1962: Včasnostredoveké pohrebisko v Nitre, SlArch X, 175-219.

JAKAB, J., 1993: Antropologische Analyse des Gräberfeldes in Komárno-Schiffswerft II, SlArch XLI, 309-329. 
JAKAB, J.-VONDRÁKOVÁ, M., 1982: Antropológia kostier z 8. storočia z pohrebísk v Komárne, SlArch XXX, 395-427.

KOLENA, B.-LUPTÁKOVÁ, L., 2009: Antropologická analýza jedinca 78/06, Monumentorum Tutela 21, 91-96.

KRASKOVSKÁ, L., 1963: Slovanské pohrebisko v Devíne (Staré Vinohrady), SlArch XI, 391-406.

- 1966: Slovanské pohrebisko v Blatnom, Zborník Slovenského národného múzea 60 - História 6, 95-114.

- 1972: Slovansko-avarské porebisko pri Záhorskej Bystrici. Martin.

KREKOVIČ, E., 2011: Archeológia detí - úvod do problematiky, Zborník FF UK Musaica XXVII, $185-192$.

LILLEHAMMER, G., 1989: A child is born: the child's world in an archaeological perspective, Norwegian Archaeological Review 22, 89-105. DOI 10.1080/00293652.1989.9965496

MAYNARD, T.-THOMAS, N., 2004: An Introduction to Early Childhood Studies. London.

MĚCHUROVÁ, Z., 2010: Středověký svět dětí a her v archeologických pramenech - Die mittelalterliche Welt der Kinder und Spiele in archäologischen Quellen, AH 35, 95-107.

MOLNÁROVÁ, M., 2015: Deti vo včasnom stredoveku z pohl'adu archeológie. Nepublikovaná diplomová práca, Katedra archeológie FF UKF v Nitre.

MOORE, J.-SCOTT, E. C., 1997: Invisible People and Processes: Writing Gender and Childhood into European Archaeology. Leicester.

NĚMEJCOVÁ-PAVÚKOVÁ, V., 1962: Belobrdské pohrebisko v Rovinke, okres Bratislava-vidiek, AR XIV, 657-691.

NODL, M., 1996: Dětství v době předhistorické, Souvislosti 7, 7-29.

- 2006: Dvě tváře dětství. Malí dospělí a děti hříšníci ve středověku, Dějiny a současnost 28, 30-33.

PLACHÁ, V.-HLAVICOVÁ, J.-KELLER, I., 1990: Slovanský Devín. Bratislava.

PROFANTOVÁ, N., 2005: Elita v zrcadle dětských pohřbů 9. a 10. století v Čechách, ŠZ AÚ SAV 37, 63-79.

REJHOLCOVÁ, M., 1995: Pohrebisko v Čakajovciach (9.-12. storočie). Katalóg. Bratislava.

RUTTKAY, A., 2005: Archeologický výskum Kostola sv. Michala v Drážovciach a na jeho okolí. In: Dávne dejiny Nitry a okolia vo svetle najnovších archeologických nálezov (Ruttkay, M., ed.), 99-108. Nitra.

SCHÜTTE, S., 1979: Spielzeug aus Göttinger Bodenfunden, Göttinger Jahrbuch 27, 55-62.

SLIVKA, M., 1998: Diet’a na prvej i poslednej ceste. Pochovávanie detí v nádobách, Hieron 2, 71-86.

- 2014: Pohl'ady do stredovekých dejín. Martin.

SMETÁNKA, Z., 1992: Legenda o Ostrojovi: Archeologie obyčejného života v raně středověkých Čechách. Praha.

- 1993: Archeologie dětství, Historický obzor 4, 78-82.

- 2003: Archeologické etudy. Praha.

SOFAER-DEREVENSKI, J., 1994: Where are all children? Accessing children in the past, Archaeological review from Cambridge 13, 7-20.

- 1997: Engendering children, engendering archaeology. Leicester.

STAŠŠÍKOVÁ-ŠTUKOVSKÁ, D.-HLOŽEK, M., 2009: Materiál korálikov z hrobu č. 78 z Kostolian pod Tribečom, Monumentorum Tutela 21, 73-90.

ŠOLLE, M., 1966: Stará Kouřim a projevy velkomoravské kultury v Čechách. Praha.

TOČÍK, A., 1968: Slawisch-awarisches Gräberfeld in Holiare. Bratislava.

- 1968a: Slawisch-awarisches Gräberfeld in Štúrovo. Bratislava.

- 1971: Flache Gräberfelder aus dem IX. und X. Jahrhundert in der Südwestslowakei, SlArch XIX, 135-276.

- 1992: Materiály k dejinám južného Slovenska v 7.-14. storočí, ŠZ AÚ SAV 28, 5-248.

TRUGLY, A., 1993: Gräberfeld aus der Zeit des Awarischen Reiches bei der Schiffswerft in Komárno II, S1Arch XLI, 191-236.

UNGER, J., 2002: Pohřební ritus 1. až 20. století v Evropě z antropologicko-archeologické perspektivy. Panorama biologické a sociokulturní antropologie. Brno.

- 2007: Pohřební ritus a proměny chápání cesty dítěte na druhý svět v prvním a druhém tisíciletí, ŠZ AƯ SAV 42, 211-220.

VACHU゚T, P.-HLADÍK, M., 2010: Nálezy raně středověkých keramických chrastítek ve tvaru vejce z Moravy. In: Zaměřeno na středověk. Zdeňkovi Měřínskému k 60. narozeninám, 203-211. Brno.

VÁŇA, Z., 1988: Archeologické doklady kultu a magie u Slovanů, SlArch XXXVI, 343-350.

WAWRZENIUK, J., 2004: Symbolika jajka w grobie dziecka w okresie wczesnosredniowiecznym, Funeralia Lednickie 6, 143-154.

ZÁBOJNÍK, J., 2004: Slovensko a avarský kaganát. Bratislava.

- 2015: Zum Verhältnis zwischen Archäologie und Anthropologie am Beispiel frühmittelalterlicher Gräberfelder aus dem Mitteldonauraum (7.-10. Jahrhundert). In: „Castelum, civitas, urbs“ (Heinrich-Tamása, O., ed.), 277-292. Leidorf. 


\section{Zusammenfassung}

\section{Das Element des Kindes im Spiegel der archäologischen Quellen des frühen Mittelalters}

Die Frage zur Stellung der Kinder in der Hierarchie der einzelnen Gemeinschaften, „Leben des Kindes" im buchstäblichen Wortsinn, die Beziehung zwischen Individuen im Erwachsenenund Kindesalter im Rahmen einer Gemeinschaft - das sind Fragen, auf welche in heutiger Zeit ein beträchtlicher Teil der Fachgemeinde Antworten zu geben bestrebt ist, die sich mit der genannten Problematik, auch was die mitteleuropäische Umgebung betrifft, beschäftigt. Entgegen dem heute vorzuherrschen beginnenden Trend einer interdisziplinären Herangehensweise an die besagte Problematik, stellt für den mitteleuropäischen Raum gerade das archäologische Material die primäre Informationsquelle dar. Unser Quellenfundus besteht aus 2661 Kindergräbern von 134 Fundstellen auf slowakischem Gebiet aus dem 6.-12. Jahrhundert. Anhand einer Analyse und Auswertung des Grabinventars sowie der Elemente des Begräbnisritus dieser Kindergräber können einige spezielle Erscheinungen ausgemacht werden, welche die Stellung der Kinder, bzw. Ihre Rolle in der damaligen Gesellschaft demonstrieren.

Eine von ihnen ist die Frage nach der sozialen Stellung von Kinderindividuen in der jeweiligen Gemeinschaft. Aus Sicht der Archäologie können diesbezüglich Kinderindividuen identifiziert werden, die der höheren (höchsten) Schicht der damaligen Gesellschaft angehörten. Ihre elitäre Stellung kann - ähnlich wie auch bei erwachsenen Individuen - aufgrund der besonderen Gestaltung der Grabgruben, anhand von prachtvollen Grabbeigaben und wegen der außergewöhnlichen Lage dieser Gräber im Rahmen eines Gräberfeldes demonstriert werden.

Ein möglicher Ausdruck des Interesses am Kind, ggf. der Sorge um ein Kind, kann - diesmal ohne Rücksicht auf dessen soziale Stellung - anhand des speziellen Grabinventars beobachtet werden. In dem untersuchten Komplex befinden sich auch Kindergräber, die Gegenstände mit vermutlicher Schutzfunktion, bzw. apotropäischer Funktion enthalten. Diese hatten die Aufgabe, das Kind vor bösen Kräften und Geistern oder sonstiger Unbill zu beschützen. Dabei handelt es sich vor allem um Glöckchen, mondsichel- und herzförmige Anhänger, ggf. Münzen in Form eines Totenobolus oder sonstige Gegenstände wie beispielsweise durchbohrte Tierzähne, Fischwirbel und Muscheln, die zusammen mit den weiter oben genannten Gegenständen als Bestandteile einer Halskette in die Kindergräber gelegt wurden.

Ein gewisses Niveau der Kindespflege, bzw. ein möglicher Beleg für eine der natürlichsten Kindesaktivitäten ist Spielzeug. „Klassisches“ mittelalterliches Spielzeug wie wir es aus der mitteleuropäischen (und auch weiteren) Umgebung kennen - beispielsweise Spielsteine und Würfel, Kugeln, Menschen, Tiere oder Phantasiegestalten darstellende Tonfiguren - ist in frühmittelalterlichen Kindergräbern auf dem Gebiet der Slowakei bislang nicht entdeckt worden. Aufgrund dessen sind wir nicht dazu in der Lage, das erwähnte Phänomen näher zu spezifizieren.

Im Zusammenhang mit der gegebenen Problematik können wir anhand von archäologischen Quellen weitere sehr interessante Phänomene ausmachen. Da es um Erscheinungen geht, die für jene Zeit spezifisch waren, bieten sich heute eher mehrere Hypothesen und Annahmen als konkrete Erklärungen an. Solchen Erscheinungen lassen sich gerade Einzelbestattungen von Kinderindividuen in Siedlungen zuordnen. Ähnlich schwierig ist auch die Interpretation von Gräbern mit Kinderindividuen, die würdelos in Siedlungsobjekten bestattet wurden. Ein weiteres Spezifikum sind Kindergräber, die sich am Rande von Gräberfeldern befinden. Da ihre Interpretation unklar ist, können sie allgemein als Zeugnis von der Stellung eines Kindes, bzw. der Kinder in einer konkreten Gemeinschaft zu der betreffenden Zeit und im jeweiligen Raum angesehen werden.

Ein spezielles Phänomen, dem wir in der Zeit des Khaghanats der Awaren bis zum Ende des Frühmittelalters begegnen, sind Gräber von Kindern, die mit anderen Individuen - Frauen, Männer oder Kinder - bestattet wurden. Die Gründe für diesen Ritus gehen nicht über die Ebene von mehreren Hypothesen hinaus. Ein möglicher Grund könnte die Blutsverwandtschaft 
zwischen so bestatteten Individuen sein, d.h. Kinder wurden mit Eltern oder Geschwistern bestattet. Auch ist die Möglichkeit nicht ausgeschlossen, dass dadurch der soziale Status eines Verstorbenen und gleichzeitig auch dessen sicherer Übergang ins Jenseits, bzw. die Garantie eines zufriedenen Lebens nach dem Tod zum Ausdruck gebracht wurde, wobei gerade das Kind als Vermittler dienen sollte.

Ein weiteres, im Hinblick auf die Interpretation problematisches Phänomen, dem wir bei der Auswertung begegnen, ist das Vorhandensein von Gegenständen des täglichen Gebrauchs. In diesem Zusammenhang kommt die Frage über die symbolische Bedeutung der betreffenden Gegenstände bei der Bestimmung der primären Rolle von Kindern im Alltag auf. Aus der Analyse solcher Artefakte geht hervor, dass man sie weder als Gegenstände im Kontext ihrer realen Verwendung im Leben, noch als Spiegelung der alltäglichen Aktivitäten eines Kindes verstehen kann. Hier stellt sich die Frage, warum die Gegenstände den Kindergräbern beigegeben wurde, welche Funktion sie hatten, ggf. ob sie eine tiefere symbolische Bedeutung hatten, die von uns bislang noch nicht erkannt wurde.

Durch die archäologische Forschung können auch solche Erscheinungen des Begräbnisritus nachvollzogen werden, die heute das Gefühl hervorrufen, dass der sich im Kindesalter befindende Teil der Population im frühen Mittelalter einer unmenschlichen Behandlung ausgesetzt war. Die im vorliegenden Beitrag aufgeführten speziellen Fälle solcher Kindergräber geben uns bis zu einem gewissen Grad Auskunft über die Beziehung der Hinterbliebenen zu den sich im Kindesalter befindenden Mitgliedern der damaligen Gemeinschaften.

Mgr. Martina Molnárová, A. Hlinku 445/17, SK 97101 Prievidza, Slovenská republika, molnarova.mata@gmail.com

Mgr. Zuzana Borzová, PhD., Katedra archeológie Filozofickej fakulty Univerzity Konštantína Filozofa v Nitre, Hodžova 1, SK 94974 Nitra, Slovenská republika, zborzova@ukf.sk 